\title{
MANIFESTASI AKUNTANSI SYARIAH DALAM ETIKA BISNIS ISLAM
}

\author{
Ridwan Tabe ${ }^{1}$
}

\begin{abstract}
ABSTRAK
Tulisan ini membahas tentang manifestasi akuntansi syariah dalam etika bisnis Islam, dengan berdasar pada konsep akuntansi syariah dan standar etika bisnis yang diatur dalam bisnis Islam, meskipun tidak membahas secara rinci tentang akuntansi syariah, namun dalam melihat keterpaduan antara konsep dan etika dapat diambil satu makna bahwa keduanya saling sejalan. Dimana konsep akuntansi syariah didasarkan pada pertanggungjawaban, keadilan, dan kebenaran. Sedangkan etika bisnis merupakan penerapan tanggung jawab sosial yang mencakup bagaimana kita menjalankan bisnis secara adil (fairness), jujur, dan bijaksana. Kemudian konsep dan etika tersebut bila dicermati surat AlBaqarah ayat 282, Allah SWT memerintahkan untuk melakukan penulisan secara benar atas segala transaksi yang pernah terjadi selama melakukan muamalah. Pada intinya ayat ini berkaitan dengan proses catat mencatat (akuntansi) dalam kegiatan bisnis dengan konsep accountability atau pertanggungjawaban, kejujuran, keadilan dan kebenaran.Melakukan kegiatan bisnis dengan etika Islam berarti menerapkan bagian akuntansi syariah.
\end{abstract}

Kata Kunci: Konsep akuntansi syariah, etika bisnis Islam

\section{A. Pendahulan}

Islam sebagai suatu agama telah ditempatkan sebagai suatu pilihan dan sekaligus ajarannya dijadikan pedoman dalam kehidupan umat manusia yang memeluknya. Sehingga keberadaannya telah memberikan arahan dalam pengembangan peradaban umat manusia. Utamanya dalam ilmu pengetahuan dan teknologi. Islam adalah agama bersifat terbuka, yang selalu memberikan keleluasan kepada umatnya untuk berpikir kedepan, dalam rangka mencapai tingkat peradaban dan kemajuan yang lebih baik ${ }^{2}$. Islam yang menurut bahasa berarti keselamatan dan kepatuhan, yang penganutnya harus senantiasa patuh

\footnotetext{
${ }^{1}$ Dosen tetap Jurusan Syariah STAIN Manado

${ }^{2}$ Muhammad. Pengantar akuntansi Syariah. (Edisi 2, Jakarta: Salemba Empat, 2005) h.7.
} 
kepada Allah dan menghargai tujuan penciptaannya di dunia, sebagaimana dijelaskan dalam Q.S. Adz Zariaat: $56^{3}$ :

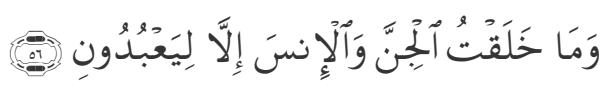

Artinya: Dan Aku tidak menciptakan jin dan manusia melainkan supaya mereka beribadah kepada-Ku.

Berdasarkan dari ayat tersebut, maka semua aktivitas yang dilakukan oleh seorang muslim senantiasa didasari dengan aturan yang telah digariskan dari Allah SWT, termasuk dalam transaksi bisnis. Tradisi Islam seluruh etika yang dijadikan kerangka bisnis harus dibangun atas dasar syariah, karena syariah merupakan pedoman yang digunakan oleh umat Islam untuk berprilaku dalam segala aspek kehidupan. Bagi umat Islam kegiatan bisnis tidak akan pernah terlepas dari ikatan syariah. Etika bisnis yang disyaratkan oleh akuntansi syariah yakni etika bisnis yang akan membuat masing-masing pihak merasa nyaman dan tenang, bukan saling mencurigai.

Etika bisnis dalam Islam telah dituangkan dalam hukum bisnis Islam yang biasa disebut dengan muamalah. Aktivitas ekonomi yang bertujuan untuk memanuhi kebutuhan hidup manusia mempunyai aturan-aturan tertentu, sebut saja aturan dalam hal jual beli, pinjam meminjam, utang mengutang, berinvestasi, kerjasama bisnis, menggunakan jaminan, dan masih banyak jenis transaksi lainnya, yang tentunya selalu didasari dengan konsep akuntansi syariah, sebagiamana tertuang dalam Al-Quran surat Al-Baqarah ayat 282, bahwa kewajiban bagi umat beriman untuk menulis setiap transaksi yang dilakukan yang masih belum tuntas. Artinya perintah tersebut ditekankan pada keadilan, kebenaran dan pertanggungjawaban agar pihak yang terlibat dalam transkasi itu tidak dirugikan.

Bentuk akuntansi yang memacarkan nilai keadilan, kebenaran, dan pertanggungjawaban sangat penting sebab informasi akuntansi memiliki kekuatan

\footnotetext{
${ }^{3}$ Q.S. Adz Zariaat: 56
} 
untuk mempengaruhi pemikiran, pengambilan keputusan dan tindakan yang dilakukan oleh seseorang.

\section{B. Pembahasan}

\section{Pengertian Akuntansi Syariah}

Akuntansi merupakan hal penting dalam bisnis. Sebab seluruh pengambilan keputusan bisnis didasarkan informasi yang diperoleh dari akuntansi. Pada setiap tahapan penambilan keputusan keberadaan informasi mempunyai peranan yang sangat penting, baik mulai dari proses pengindentifikasi persoalan, mencarai alternative pemecahan persoalan, maumpun memonitor pelaksanaan keputusan yang diterapkan. Apabila proses tersebut dikaitkan dengan operasionalisasi suatu perusahaan, maka informasi akuntansi inilah yang sangat dibutuhkan ${ }^{4}$. Untuk mencari sumber informasi, maka perlu ditelusuri akar filosofisnya dengan cara menelusuri Al-Quran sebagai sebagai sumber informasi dan sumber ilmu bagi manusia. Ternata konsep akuntansi syariah telah diajarkan dalam Al-Quran, dengan konsep accountability atau pertanggungjawaban ${ }^{5}$. Dinyatakan dalam surah al-Baqarah ayat $282^{6}$ :

Artinya: "Hai orang-orang yang beriman, apabila kamu bermuamalah tidak secara tunai untuk waktu yang ditentukan, hendaklah kamu menuliskannya. dan hendaklah seorang penulis di antara kamu menuliskannya dengan benar. dan janganlah penulis enggan menuliskannya sebagaimana Allah mengajarkannya, meka hendaklah ia menulis, dan hendaklah orang yang berhutang itu mengimlakkan (apa yang akan ditulis itu), dan hendaklah ia bertakwa kepada Allah Tuhannya, dan janganlah ia mengurangi sedikitpun daripada hutangnya. jika yang berhutang itu orang yang lemah akalnya atau lemah (keadaannya) atau

\footnotetext{
${ }^{4}$ M. Akhyar Adnan. Akuntansi Syariah Arah, Prospek dan Tantangan. (Cetakan ke-2, Yogyakarta, UII Press, 2005), h. 6. 2000), h. 5 .

${ }^{5}$ Muhammad. Prinsip-prinsip Akuntansi Dalam Al-Quran. (Yogyakarta: UII Press,
}

${ }^{6}$ Q.S. Al-Baqarah: 282 
dia sendiri tidak mampu mengimlakkan, Maka hendaklah walinya mengimlakkan dengan jujur. dan persaksikanlah dengan dua orang saksi dari orang-orang lelaki (di antaramu). jika tak ada dua oang lelaki, Maka (boleh) seorang lelaki dan dua orang perempuan dari saksi-saksi yang kamu ridhai, supaya jika seorang lupa Maka yang seorang mengingatkannya. janganlah saksi-saksi itu enggan (memberi keterangan) apabila mereka dipanggil; dan janganlah kamu jemu menulis hutang itu, baik kecil maupun besar sampai batas waktu membayarnya. yang demikian itu, lebih adil di sisi Allah dan lebih menguatkan persaksian dan lebih dekat kepada tidak (menimbulkan) keraguanmu. (Tulislah mu'amalahmu itu), kecuali jika mu'amalah itu perdagangan tunai yang kamu jalankan di antara kamu, Maka tidak ada dosa bagi kamu, (jika) kamu tidak menulisnya. dan persaksikanlah apabila kamu berjual beli; dan janganlah penulis dan saksi saling sulit menyulitkan. jika kamu lakukan (yang demikian), Maka Sesungguhnya hal itu adalah suatu kefasikan pada dirimu. dan bertakwalah kepada Allah; Allah mengajarmu; dan Allah Maha mengetahui segala sesuatu”.

Ayat tersebut menunjukkan kewajiban bagi umat beriman untuk menulis setiap transaksi yang dilakukan dan masih belum tuntas. Tujuan perintah surat tersebut adalah untuk menjaga keadilan dan kebenaran. Artinya perintah tersebut ditekankan pada pertanggungjawaban agar pihak yang terlibat dalam transkasi itu tidak dirugikan, sehingga tidak menimbulkan konflik, dan untuk menciptakan transaksi yang adil maka diperlukan saksi dari ayat tersebut kemudian diturunkan menjadi konsepsi akuntansi syariah yang sarat dengan nilai.

Cara demikian, realitas alternatif diharapkan akan dapat membangkitkan kesadaran diri secara penuh akan kepatuhan dan ketundukan seseorang kepada kuasa Allah. Dengan kesaaran diri tersebut, ia akan selalu merasakan kehadiran Tuhan dalam dimensi waktu dan tempat dimana ia berada. Melalui akuntansi syariah realitas sosial akan dikostruk melalui muatan tauhid dan ketundukan pada jaringan kuasa Ilahi, yang semuanya dilakukan dengan perspektif khalifat-ullah fil 
ardh, yaitu suatu cara pandang yang sadar akan hakikat diri manusia dan tanggungjawab kelak dikemudian hari dihadapan Allah $\mathrm{SWT}^{7}$.

\section{Prinsip Akuntansi Syariah}

Dalam mencermati surat Al-Baqarah ayat 282, Allah SWT memerintahkan untuk melakukan penulisan secara benar atas segala transaksi yang pernah terjadi selama melakukan muamalah. Dari hasil penulisan tersebut dapat digunakan untuk manentukan apa yang akan diperbuat oleh seseorang. Dalam hal ini Allah sudah menggariskan bahwa konsep akuntansi adalah penekanan pada pertanggungjawaban, keadilan, dan kebenaran. Ketiga konsep tersebut tentu saja telah menjadi prinsip dasar yang universal dalam operasional akuntansi syariah. Berikut uraian ketiga prinsip yang terdapat dalam surat Al-Baqarah: $282^{8}$.

1. Prinsip Pertanggungjawaban

Prinsip pertanggungjawaban atau accountability merupakan konsep yang tidak asing lagi dikalangan masyarakat muslim. Pertanggungjawaban selalu berkaitan dengan konsep amanah. Bagi kaum muslim, persoalan amanah merupakan hasil transaksi manusia dengan sang khaliq mulai dari alam kandungan. Manusia diciptakan oleh Allah sebagai khalifah dimuka bumi. Manusia dibebani oleh amanah oleh Allah untuk menjalankan fungsi-fungsi kekhalifahannya. Initi kekhalifahan adalah menjalankan atau menunaikan amanah.

Banyak ayat Al-Qur'an yang menjelaskan tentang proses pertanggungjawaban manusia sebagai pelaku amanah Allah dimuka bumi. Implikasi dalam bisnis dan akuntansi adalah bahwa individu yang terlibat dalam praktik bisnis harus selalu melakukan pertanggungjawabanapa yang telah diamanatkan dan diperbuat kepada pihak-pihak yang terkait. Wujud pertanggungjawaban biasanya dalam bentuk laporan akuntansi.

\footnotetext{
7 Iwan Triyuwono, Perspektif, Metodologi, dan Teori Akuntansi Syariah, (Jakarta: RajaGrapindo Persada, 2006). h. 65.

${ }^{8}$ Muhammad. Pengantar ......, Op. cit., h. 11-12
} 


\section{Prinsip Keadilan}

Prinsip keadilan ini tidak saja merupakan nilai yang sangat penting dalam etika kehidupan sosial dan bisnis, tetapi juga merupakan nilai inheren melekat dalam fitrah manusia. Ini berarti bahwa manusia itu pada dasarnya memiliki kapasitas dan energi untuk berbuat adil dalam setiap aspek kehidupannya.

Dalam konteks akuntansi, menegaskan, kata adil dalam ayat 282 surat AlBaqarah, secara sederhana dapat berarti bahwa setiap transaksi yang dilakukan oleh perusahaan dicatat dengan benar. Dengan demikian kata keadilan dalam konteks aplikasi akuntansi mengandung dua pengertian: pertama, berkaitan dengan praktik moral, yaitu kejujuran karena tanpa kejujuran informasi akuntansi yang disajikan akan merugikan masyarakat. Kedua, kata adil bersifat lebih fundamental dan tetap berpijak pada nilai-nilai etika/syariah dan moral.

\section{Prinsip Kebenaran}

Prinsip kebenaran ini sebenarnya tidak dapat dilepaskan dengan keadilan. Sebagai contoh dalam akuntansi kita selalu dihadapkan pada masalah pengakuan, pengukuran dan pelaporan. Aktivitas ini dapat dilakukan dengan baik apabila dilandaskan pada nilai kebenaran. Kebenaran ini dapat menciptakan keadilan dalam mengakui, mengukur, dan melaporkan transaksitransksi ekonomi. Kebenaran dalam Al-Qur'an tidak diperbolehkan untuk dicampur-adukkan dengan kebathilan.

\section{Etika Bisnis Dalam Islam}

Islam merupakan sumber nilai dan etika dalam segala aspek kehidupan manusia secara menyeluruh, termasuk wacana bisnis. Islam memiliki wawasan yang komprehensif tentang etika bisnis. Mulai dari prinsip dasar, faktor-faktor produksi, tenaga kerja, modal organisasi, distribusi kekayaan, masalah upah, barang dan jasa, kualifikasi dalam bisnis, sampai kepada etika sosio ekonomik menyangkut hak milik dan hubungan sosial. Aktivitas bisnis merupakan bagian integral dari wacana ekonomi. Sistem ekonomi Islam berangkat dari kesadaran 
tentang etika, Etika bisnis akan membuat masing-masing pihak merasa nyaman dan tenang, bukan saling mencurigai. Etika bisnis dalam Islam telah dituangkan dalam hukum bisnis Islam yang biasa disebut dengan muamalah. Aktivitas ekonomi yang bertujuan untuk memenuhi kebutuhan hidup manusia mempunyai aturan-aturan tertentu. Berikut etika bisnis yang diatur dalam Islam diantaranya ${ }^{9}$ :

1. Menghindari tirani, setan, sombong, serakah, dan lain-lain yang jelek

2. Menjamin self defendece dan self worth

3. Kerjasama dengan yang lain, baik waktu susah maupun waktu gembira

4. Mematuhi peraturan dari tiap perjanjian

5. Membeli dan menjual dengan cara sopan dan sederhana

6. Jangan menipu, berbohong, sewaktu membeli dan menjual

7. Menghindari transaksi jika ada keraguan tentang kesesuaianya dengan prinsip Islam

8. Jangan biarkan pedagang yang tidak mengetahui sopan dan etika bisnis menjual dipasar

9. Berikan toleransi dalam transkasi peminjaman, jika tidak mampu membayar pada waktu jatuh tempo

10. Jangan menjual barang yang dilarang oleh Islam

11. Jangan melakukan pembelian komoditi di depan karena yang dibeli bisa berubah pada saat pengirimannya

12. Bayar utang pada tanggal jatuh tempo

13. Jangan memakan riba (bunga) Islam membenarkan menginvestasi uang, tetapi investasi yang membebani bungayang akan dibayar dilarang dan dianggap tidak etis

14. Pakai timbangan yang adil, ukuran yang benar, sehingga tidak ada yang dirugikan dengan cara curang

15. Jangan membeli dan menjual produksi yang dicuri

16. Jangan berjudi untuk tujuan apapun termasuk lotere

${ }^{9}$ Sofyan Ayafri Harahap, Akuntansi Islam, Jakarta: Bumi Aksara, 2001, hal. 236. 
Ke-16 standar etika ini dapat dianggap sebagai kode etik bisnis Islam, mendorong ketaatan dan menolak prilaku tidak etis, etika bisnis yang merupakan tanggung jawab soial yang adil, jujur, dan bijaksana

\section{Etika dan Standar Akuntansi Islam}

Kata etika berasal dari bahasa Yunani yaitu " Ethos" yang berarti adat, akhlak, waktu perasaan, sikap dan cara berfikir atau adat-istiadat. Etik adalah suatu studi mengenai yang benar dan yang salah dan pilihan moral yang dilakukan oleh seseorang ${ }^{10}$. Etika adalah tuntutan mengenai perilaku, sikap dan tindakan yang diakui, sehubungan suatu jenis kegiatan manusia, etika tidak berbicara tentang kalah menang, melaikan berbicara tentang baik dan apa yang wajar dan sesuai dengan norma ${ }^{11}$. Etika bisnis merupakan penerapan tanggung jawab sosial yang adil, jujur, dan bijaksana suatu bisnis yang timbul dari dalam perusahaan itu sendiri ${ }^{12}$

Secara sederhana yang dimaksud dengan etika bisnis adalah cara-cara untuk melakukan kegiatan bisnis, yang mencakup seluruh aspek yang berkaitan dengan individu, perusahaan, industri dan juga masyarakat. Kesemuanya ini mencakup bagaimana kita menjalankan bisnis secara adil (fairness), sesuai dengan hukum yang berlaku (legal) tidak tergantung pada kedudukan individu ataupun perusahaan di masyarakat.

Berikut konsep bisnis yang diambil dari standar etika Islam $^{13}$ :

\begin{tabular}{|l|l|}
\hline Konsep Bisnis & Standar Etis \\
\hline 1. Pemilikan & 1. Pemilikan individu harus didorong dan dilindungi \\
& 2. Kekayaan adalah milik Tuhan. Individu bertindak \\
& sebagai agen dalam memiliki kekayaan \\
& 3. Pemilikan public termasuk kekayaan mineral air, dan \\
\hline
\end{tabular}

\footnotetext{
${ }^{10}$ Arius Akbar, Etika Bisnis dan Akuntansi dalam Islam, (artikel, 7-5-12, TP.T.Th).

11 Moh. Alifuddin, Menjadi Wirausaha Sukses Abadi Abad ke-21, (Jakarta, Yapensi,

${ }^{12}$ Ibid.

${ }^{13}$ Suyanto, Manifestasi Nilai-nilai Islam dalam Akuntansi, dalam Harahap, Akuntansi Islam, (Jakarta: Bumi Aksara, 2001, hal. 235.
} 2001), hal. 83 . 


\begin{tabular}{|c|c|}
\hline & $\begin{array}{l}\text { sumber energi } \\
\text { 4. Pemilik individu harus memperhatikan masyaraka dan } \\
\text { fungsi ekonomis dari kekayaan itu }\end{array}$ \\
\hline 2. Keadilan & $\begin{array}{l}\text { 1. Setiap orang berhak atas keadilan } \\
\text { 2. Kesempatan yang sama merupakan dasar keadilan } \\
\text { 3. Kecukupan merupakan dasar kedua dari keadilan } \\
\text { 4. Adalah kewajiban dari semua orang untuk berlaku adil }\end{array}$ \\
\hline 3. Harga & $\begin{array}{l}\text { 1. Harga diatur oleh pasar } \\
\text { 2. Pemerintah tidak dibenarkan mempengaruhi harga } \\
\text { 3. Pengecualian campur tangan hanya boleh untuk } \\
\text { kepentingan keadilan dan distribusi barang harus adil } \\
\text { dan lancar } \\
\text { 4. Setiap harga barang yang dijual dicantumkan agar } \\
\text { diketahui public }\end{array}$ \\
\hline 4. Persaingan & $\begin{array}{l}\text { 1. Persaingan diizinkan dan dianjurkan } \\
\text { 2. Perpindahan barang tidak boleh dihalangi, harus dijamin } \\
\text { bebas } \\
\text { 3. Persaingan tidak boleh menimbulkan monopoli } \\
\text { 4. Tidak dibenarkan campur tangan terhadap fungsi pasar }\end{array}$ \\
\hline $\begin{array}{l}\text { 5. Hubungan } \\
\text { Pimpinan dan } \\
\text { Karyawan }\end{array}$ & $\begin{array}{l}\text { 1. Majikan berhak atas kejujuran dan kemampuan } \\
\text { karyawan } \\
\text { 2. Kepemimpinan membutuhkan beban tanggung jawab } \\
\text { 3. Tiap orang adalah pemimpin dan ia bertanggung jawab } \\
\text { atas bawahan yang dipimpinnya } \\
\text { 4. Mendisiplinkan pegawai harus secara pribadi tidak } \\
\text { boleh didepan orang. }\end{array}$ \\
\hline
\end{tabular}




\section{Akuntansi dalam Kehidupan Manusia sebagai Khalifah}

Al-Quran adalah kitab suci umat isalam yang telah menjadi sumber hukum dalam mengatur kehidupan umat manusia, berkaitan dengan persoalan nasib hidup di dunia maupun pencapaian kesejahteraan hidup di akhirat yang kekal abadi ${ }^{14}$.

Allah telah mengingatkan kepada seluruh umat manusia dalam surat alQashash: 77 sebagai berikut ${ }^{15}$ :

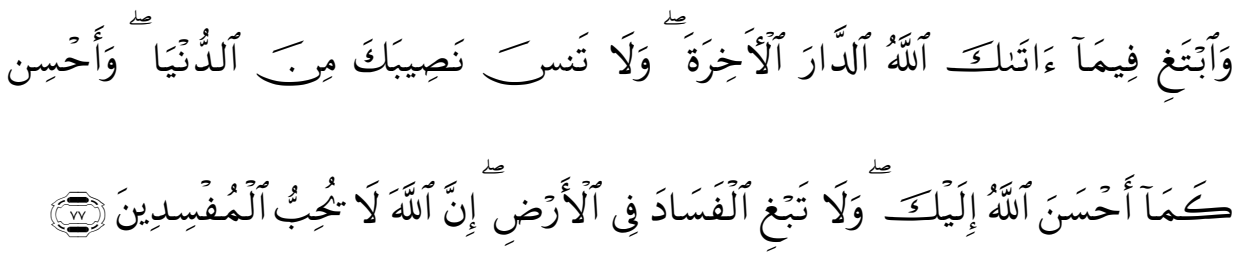

Artinya: "Dan carilah pada apa yang Telah dianugerahkan Allah kepadamu (kebahagiaan) negeri akhirat, dan janganlah kamu melupakan bahagianmu dari (kenikmatan) duniawi dan berbuat baiklah (kepada orang lain) sebagaimana Allah Telah berbuat baik, kepadamu, dan janganlah kamu berbuat kerusakan di (muka) bumi. Sesungguhnya Allah tidak menyukai orang-orang yang berbuat kerusakan”.

Selanjutnya dalam surat al-Baqarah: 208 dijelaskan $^{16}$ :

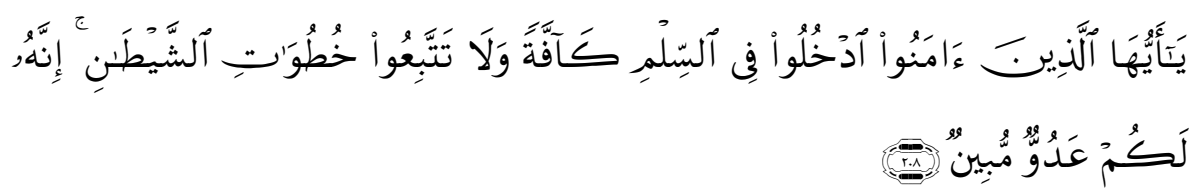

Artinya: "Hai orang-orang yang beriman, masuklah kamu ke dalam Islam keseluruhan, dan janganlah kamu turut langkah-langkah syaitan. Sesungguhnya syaitan itu musuh yang nyata bagimu”.

Dari dua ayat diatas menunjukkan bahwa didalam berusaha menerima nasib didunia maupun dalam berusaha mencapai kesejahteraan hidup diakhirat haruslah sesuai dengan petunjuk Allah yang disebut dengan agama Islam. Sebab,

\footnotetext{
${ }^{14}$ Muhammad. Prinsip-prinsip......, op. cit.. h. 50

${ }^{15}$ Q.S. Al-Qashash: 77

${ }^{16}$ Q.S Al-Baqarah: 208
} 
semua anugerah maupun semua tindakan kita pasti dipertanggungjawabkan kepada Allah ${ }^{17}$. Hal ini berarti orang yang berbuat sesuai petunjuk Allah akan mendapatkan kesejahteraan dunia dan akhirat. Sebaliknya orang yang berbuat dosa atau dhalimakan mendapatkan hukuman dari Allah. Oleh karena itu semua tingkah laku dan perbuatan manusia dalam segala bidang termasuk bidang ekonomi dan bisnis haruslah berlandaskan syariah agama Islam.

Seluruh amal perbuatan manusia sejak lahir, baliq sampai meninggal akan selalu dicatat oleh malaikat. Ditegaskan dalam surat al-Infithaar: $10-12^{18}$.

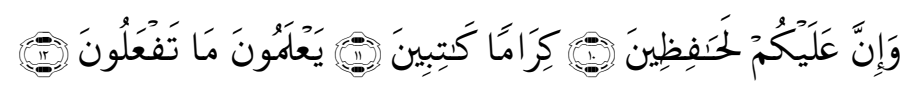

Artinya: Sesungguhnya bagi kamu ada (Malaikat-malaikat) yang Mengawasi (pekerjaanmu), yang mulia (di sisi Allah) dan mencatat (pekerjaan-pekerjaanmu itu), mereka mengetahui apa yang kamu kerjakan.

\section{Kesimpulan}

Akuntansi syariah merupakan hal penting dalam bisnis. Sebab seluruh pengambilan keputusan bisnis didasarkan informasi yang diperoleh dari akuntansi, sementara konsep akuntansi syariah didasarkan pada pertanggungjawaban, keadilan, dan kebenaran. Sedangkan etika bisnis merupakan penerapan tanggung jawab sosial yang mencakup bagaimana kita menjalankan bisnis secara adil (fairness), jujur, dan bijaksana sesuai dengan hukum yang berlaku (legal) tidak tergantung pada kedudukan individu seseorang.

Konsep akuntansi syariah dalam etika bisnis bila ditelusuri akar filosofisnya dengan cara menelusuri Al-Quran sebagai sebagai sumber informasi dan sumber ilmu bagi manusia maka dijelaskan Surat Al-Baqarah ayat 282 adalah ayat utama yang berkaitan dengan proses catat mencatat (akuntansi) dalam kegiatan bisnis. Pada intinya ayat tersebut mengajarkan kepada manusia agar

\footnotetext{
17 Muhammad, Prinsip-prinsip ...., op. cit. h. 51.

18 Q.S Al-Baqarah: 208
} 
kegiatan bisnis dilakukan sesuai dengan konsep accountability atau pertanggungjawaban, kejujuran, keadilan dan kebenaran.

Segala aktivitas dalam bisnis, berusaha mencapai kesejahteraan hidup diakhirat haruslah sesuai dengan petunjuk Allah yang disebut dengan agama Islam. Sebab, semua anugerah maupun semua tindakan kita pasti dipertanggungjawabkan kepada Allah, melalui akuntansi syariah realitas sosial akan dikostruk melalui muatan tauhid dan ketundukan pada jaringan kuasa Ilahi, yang semuanya dilakukan dengan perspektif khalifat-ullah fil ardh, yaitu suatu cara pandang yang sadar akan hakikat diri manusia dan tanggungjawab kelak dikemudian hari dihadapan Allah SWT. 


\section{DAFTAR PUSTAKA}

Al-Quran dan terjemahan

Arius Akbar, Etika Bisnis dan Akuntansi dalam Islam, (artikel, 7-5-12, TP.T.Th.

Iwan Triyuwono, Perspektif, Metodologi, dan Teori Akuntansi Syariah, Jakarta: RajaGrapindo Persada, 2006.

M. Akhyar Adnan. Akuntansi Syariah Arah, Prospek dan Tantangan. Cetakan ke2, Yogyakarta: UII Press, 2005.

Moh. Alifuddin, Menjadi Wirausaha Sukses Abadi Abad ke-21, Jakarta: Yapensi, 2001.

Muhammad. Pengantar akuntansi Syariah. Edisi 2, Jakarta: Salemba Empat, 2005.

Muhammad. Prinsip-prinsip Akuntansi Dalam Al-Quran. Yogyakarta: UII Press, 2000.

Sofyan Ayafri Harahap, Akuntansi Islam, Jakarta: Bumi Aksara, 2001.

Suyanto, Manifestasi Nilai-nilai Islam dalam Akuntansi, dalam Harahap , Akuntansi Islam, Jakarta: Bumi Aksara, 2001. 